\title{
A Novel Lysophosphatidic Acid Acyltransferase of Escherichia coli Produces Membrane Phospholipids with a cis-vaccenoyl Group and Is Related to Flagellar Formation
}

\author{
Yosuke Toyotake $^{1,2}$, Masayoshi Nishiyama ${ }^{1}$ (D), Fumiaki Yokoyama ${ }^{1}$ (D), Takuya Ogawa ${ }^{1}$, \\ Jun Kawamoto ${ }^{1}$ (D) and Tatsuo Kurihara $1, *(\mathbb{D})$ \\ 1 Institute for Chemical Research, Kyoto University, Uji, Kyoto 611-0011, Japan; \\ toyotake@fc.ritsumei.ac.jp (Y.T.); mnishiyama@phys.kindai.ac.jp (M.N.); \\ yokoyama@mbc.kuicr.kyoto-u.ac.jp (F.Y.); ogawa.tky@mbc.kuicr.kyoto-u.ac.jp (T.O.); \\ jun_k@mbc.kuicr.kyoto-u.ac.jp (J.K.) \\ 2 Department of Biotechnology, College of Life Sciences, Ritsumeikan University, 1-1-1 Noji-higashi, \\ Kusatsu, Shiga 525-8577, Japan \\ * Correspondence: kurihara@scl.kyoto-u.ac.jp or kurihara@mbc.kuicr.kyoto-u.ac.jp; Tel.: +81-774-38-4710
}

Received: 26 March 2020; Accepted: 7 May 2020; Published: 11 May 2020

\begin{abstract}
Lysophosphatidic acid acyltransferase (LPAAT) introduces fatty acyl groups into the sn-2 position of membrane phospholipids (PLs). Various bacteria produce multiple LPAATs, whereas it is believed that Escherichia coli produces only one essential LPAAT homolog, PlsC—-the deletion of which is lethal. However, we found that E. coli possesses another LPAAT homolog named YihG. Here, we show that overexpression of YihG in E. coli carrying a temperature-sensitive mutation in $\mathrm{pls} \mathrm{C}$ allowed its growth at non-permissive temperatures. Analysis of the fatty acyl composition of PLs from the yihG-deletion mutant $(\Delta y i h G)$ revealed that endogenous YihG introduces the cis-vaccenoyl group into the $s n-2$ position of PLs. Loss of YihG did not affect cell growth or morphology, but $\Delta y i h G$ cells swam well in liquid medium in contrast to wild-type cells. Immunoblot analysis showed that FliC was highly expressed in $\Delta y i h G$ cells, and this phenotype was suppressed by expression of recombinant YihG in $\Delta y i h G$ cells. Transmission electron microscopy confirmed that the flagellar structure was observed only in $\Delta y i h G$ cells. These results suggest that YihG has specific functions related to flagellar formation through modulation of the fatty acyl composition of membrane PLs.
\end{abstract}

Keywords: lysophosphatidic acid acyltransferase; membrane phospholipid diversity; swimming motility; flagellar formation

\section{Introduction}

Phospholipids (PLs) are the primary component of biological membranes. They consist of a phosphate-containing head group and two fatty acyl groups. The structural diversity of these fatty acyl groups affects the physical state of biological membranes such as fluidity, permeability, rigidity, and thickness [1-4]. Bacteria maintain the ideal physical state of their membrane in response to environmental changes by modulating the fatty acyl groups of membrane PLs. For example, as environmental temperature decreases, bacteria generally introduce lower-melting-point fatty acyl groups such as unsaturated fatty acyl groups and branched-chain fatty acyl groups into membrane PLs [5-13]. However, it is still not fully understood how bacteria regulate the fatty acyl composition of membrane PLs in response to environmental changes. 
During the de novo synthesis of PLs [14-17], fatty acyl groups are incorporated into the $s n-1$ and sn-2 position by glycerol-3-phosphate acyltransferases and lysophosphatidic acid acyltransferases (LPAATs), respectively [18-23]. In some bacteria, such as Neisseria meningitidis, Pseudomonas fluorescens, Pseudomonas aeruginosa, and Rhodobacter capsulatus, multiple LPAAT homologs have been identified and characterized [24-27]. These LPAATs potentially play different roles in vivo to contribute to the generation of diversity in membrane PLs.

Shewanella livingstonensis Ac10 is a psychrotrophic bacterium used as a model of cold-adapted organisms [9,28-31]. This bacterium has five LPAAT homologs (SIPlsC1 to SIPlsC5) [32]. We previously reported that SIPlsC1 plays a major role in the synthesis of PLs containing polyunsaturated fatty acyl groups [32,33], while SIPlsC4 is mainly responsible for the synthesis of PLs containing branched-chain fatty acyl groups (i13:0 and i15:0) [34]. Some marine bacteria such as Alteromonas mediterranea and Colwellia psychrerythraea have a putative SIPlsC4 ortholog. These bacteria also have an SIPlsC1 ortholog, suggesting that the multiple LPAAT homologs introduce specific fatty acyl groups into membrane PLs for their adaptation to the marine environment, as has been shown in S. livingstonensis Ac10. Likewise, it is conceivable that uncharacterized LPAAT homologs also exist in other bacterial species to generate membrane lipid diversity to allow environmental adaptation.

It has long been believed that Escherichia coli has only one essential LPAAT homolog, named $\mathrm{PlsC}$ - the deletion of which is lethal [35]. However, we found that E. coli possesses an SIPlsC4 ortholog named YihG. YihG was originally thought to be a second poly(A) polymerase [36], but this claim has subsequently been denied [37]. Even though YihG can be considered as an inner membrane protein belonging to a 1-acyl-sn-glycerol-3-phosphate $O$-acyltransferase family based on its conserved catalytic motif [38,39], the sequence identity between YihG and E. coli PlsC is $17.9 \%$, and thus YihG has not been recognized as a functional LPAAT homolog. Sutton and co-workers previously reported that overproduction of YihG suppresses the hyperinitiation of DNA replication and resulting growth defect in E. coli, presumably by regulating the level of ATP-binding DnaA (DnaA-ATP), an activator for the initiation of DNA replication [40]. However, no one has yet clarified whether YihG has LPAAT activity or investigated how YihG affects the membrane lipid composition. YihG is conserved in some $\gamma$-proteobacteria such as P. aeruginosa, Salmonella typhimurium, and Vibrio cholerae. Thus, we hypothesized that an SIPlsC4 ortholog has a physiological function in various $\gamma$-proteobacteria including some enteric and pathogenic bacteria.

In this study, we demonstrated that YihG is a functional LPAAT homolog by complementation assay using the E. coli strain JC201, a temperature-sensitive $p l s C$ mutant. We found that YihG has a different substrate specificity from PlsC, and that endogenous YihG contributes to the synthesis of PLs containing a cis-vaccenoyl group at the sn-2 position. The lack of YihG caused enhanced flagellar formation and swimming motility in the liquid medium. Thus, E. coli YihG appears to regulate bacterial swimming motility through modulation of the composition of fatty acyl groups in membrane PLs.

\section{Materials and Methods}

\subsection{Bacterial Strains, Plasmids, and Growth Conditions}

The bacterial strains and plasmids used in this study are listed in Table S1. E. coli K-12 strain BW25113 and its yihG-knockout mutant $(\Delta y i h G)$ were obtained from the National BioResource Project (NIG, Mishima, Japan). E. coli JC201 strain, which carries a temperature-sensitive mutation in plsC, was used in the complementation assay to evaluate LPAAT activity [35]. The E. coli cells were cultivated in lysogeny broth [LB; $1 \%(w / v)$ Bacto Tryptone, $0.5 \%(w / v)$ Bacto Yeast extract, and 1\% $(w / v) \mathrm{NaCl}$, tryptone broth [TB; $1 \%(w / v)$ Bacto Tryptone and $1 \%(w / v) \mathrm{NaCl}$ ], and M9-based minimal medium [48 $\mathrm{mM} \mathrm{Na}_{2} \mathrm{HPO}_{4}, 22 \mathrm{mM} \mathrm{KH}_{2} \mathrm{PO}_{4}, 19 \mathrm{mM} \mathrm{NH}_{4} \mathrm{Cl}, 8.6 \mathrm{mM} \mathrm{NaCl}, 0.1 \mathrm{mM} \mathrm{CaCl}, 1 \mathrm{mM}$ $\mathrm{MgSO}_{4}$, and $0.4 \%(w / v)$ glucose]. Growth was monitored by measuring $\mathrm{OD}_{600}$ with a UV-visible spectrophotometer (UV-2450, Shimadzu, Kyoto, Japan). Antibiotics were used, when required, at the following concentrations: kanamycin $(30 \mu \mathrm{g} / \mathrm{mL})$ and chloramphenicol $(34 \mu \mathrm{g} / \mathrm{mL})$. 


\subsection{Construction of YihG- and PlsC-Expression Plasmids}

PCR primers used in this study are listed in Table S2. The plasmid named pBAD- $\mathrm{Cm}^{\mathrm{R}}$ was created from pBAD28 [41] by digestion with ScaI and self-ligation to remove the ampicillin resistance gene. DNA fragments coding for the C-terminal hexa-histidine-tagged YihG (YihG-His 6 ) and PlsC (PlsC-His 6 ) were obtained by PCR using the BW25113 genome as a template. The resulting DNA fragments were individually introduced into the SalI-HindIII site in pBAD-Cm ${ }^{R}$ using an In-Fusion Advantage PCR cloning kit (TaKaRa Bio, Otsu, Japan) following the manufacturer's instructions. The resulting plasmids were designated $\mathrm{pBAD} / \mathrm{yihG}^{-} \mathrm{his}_{6}$ and $\mathrm{pBAD} / \mathrm{plsC}_{\mathrm{S}}-h i_{6}{ }_{6}$, respectively.

\subsection{JC201 Complementation Assay}

JC201 cells harboring pBAD-Cm ${ }^{\mathrm{R}}$ or $\mathrm{pBAD} / \mathrm{yih}$ G-his ${ }_{6}$ were cultured at $30^{\circ} \mathrm{C}$ in $\mathrm{LB}$ until the $\mathrm{OD}_{600}$ reached 1.2 to 1.4. The cell cultures were normalized to an $\mathrm{OD}_{600}$ of 1.0 and diluted to $10^{-2}, 10^{-3}, 10^{-4}$, $10^{-5}$, and $10^{-6}$ in fresh LB. Three microliters of the serial dilutions was spotted onto $1.5 \%(w / v)$ agar LB plates containing 0 to $2 \%(w / v)$ L-arabinose. The plates were incubated at 30 and $42{ }^{\circ} \mathrm{C}$ until colonies were formed.

JC201 cells harboring pBAD-Cm ${ }^{\mathrm{R}}, \mathrm{pBAD} / \mathrm{yih} \mathrm{G}-$ his $_{6}$, or $\mathrm{pBAD} /$ plsC-his $_{6}$ were cultured at $30^{\circ} \mathrm{C}$ in $\mathrm{LB}$ until an $\mathrm{OD}_{600}$ reached 1.0 to 1.8. They were diluted to an $\mathrm{OD}_{600}$ of 0.01 in $\mathrm{LB}$ containing $0.5 \%$ $(w / v)$ and $1 \%(w / v)$ L-arabinose and grown at $37^{\circ} \mathrm{C}$ for $9 \mathrm{~h}$ to monitor their growth rates. To analyze membrane lipids as described below, cells expressing YihG and PlsC with $1 \%(w / v)$ L-arabinose were grown and harvested by centrifugation at room temperature when their $\mathrm{OD}_{600}$ reached 0.6 to 0.8 .

\subsection{Total PL Extraction and Analysis by Electrospray Ionization Tandem Mass Spectrometry (ESI-MS/MS)}

BW25113 cells harboring pBAD-Cm ${ }^{\mathrm{R}}$ and $\Delta y i h \mathrm{G}$ cells harboring $\mathrm{pBAD}-\mathrm{Cm}^{\mathrm{R}}$ or pBAD/yih G-his 6 were grown in $\mathrm{TB}$ containing $0.2 \%(w / v)$ L-arabinose at $37^{\circ} \mathrm{C}$ to an $\mathrm{OD}_{600}$ of 0.4 to 0.6 and harvested by centrifugation at room temperature. The cells were flash frozen in liquid nitrogen and stored at $-80^{\circ} \mathrm{C}$ until use. The frozen cells were lyophilized, and total PLs were extracted using the Bligh and Dyer method [42]. JC201 cells harvested as described above were not lyophilized and were instead directly used for PL extraction. The extracted PLs were analyzed by ESI-MS/MS [a triple-quadrupole Sciex API $3000^{\mathrm{TM}}$ LC/MS/MS System (Applied Biosystems, Foster City, CA, USA)], as described previously [34].

\subsection{Analysis of the sn-1 and sn-2 Fatty Acyl Groups of PLs}

The PLs prepared as described above were hydrolyzed with Phospholipase A2 (PLA2, P6534, Sigma, St. Louis, MO). The resulting sn-2 fatty acyl groups were extracted by the Dole's method $[34,43,44]$ and analyzed by gas chromatography-mass spectrometry [GC-MS, Clarus 680 gas chromatograph interfaced with Clarus SQ 8C mass spectrometer (Perkin Elmer, Wellesley, MA) equipped with an Agilent J\&W GC column DB-1 (Agilent Technologies Inc., Santa Clara, CA, USA)], as described previously [45]. Lysophospholipids (LPLs) were analyzed using the total lipid extracts from an aliquot of the PLA2 reaction product by ESI-MS as described above.

\subsection{Motility Assay in Soft Agar Plates}

The BW25113 and $\Delta y$ ih $G$ cells were grown in $\mathrm{LB}$ at $37^{\circ} \mathrm{C}$ to an $\mathrm{OD}_{600}$ of 0.8 to 1.2. Two microliters of each cell culture was spotted on TB $0.2 \%(w / v)$ agar plates. For $\Delta y i h G$ cells harboring the plasmids, TB $0.2 \%(w / v)$ agar plates containing $0.02 \%(w / v)$ or $0.2 \%(w / v)$ L-arabinose were used. The plates were incubated at $37^{\circ} \mathrm{C}$ for an appropriate time, as noted in the Results section.

\subsection{Microscopic Observation of Swimming Cells}

The BW25113 and $\Delta y$ ih $G$ cells were grown at $37^{\circ} \mathrm{C}$ in $\mathrm{TB}$ to an $\mathrm{OD}_{600}$ of 0.6 to 1.3. The cultivated cells were diluted with fresh TB medium. Motility of the cells was observed at room temperature under a microscope (Ti-E, Nikon, Tokyo, Japan) [46]. The phase-contrast images of cells near the cover 
slip were recorded at video rate. All assays were repeated with four different cultures. The fraction of the swimming cells was obtained by dividing the number of cells that swam with a speed of $>2 \mu \mathrm{m} / \mathrm{s}$ by that of all cells in the focal plane. The speed of each of the swimming cells was analyzed using a custom-made plugin (Version 0.7.1) of Image J [47].

\subsection{Flagellin Preparation and Analysis by Western Blot Analysis}

The BW25113 and $\Delta y i h G$ cells were grown at $37^{\circ} \mathrm{C}$ in $\mathrm{TB}$ to an $\mathrm{OD}_{600}$ of 0.5 to 0.7 . $\Delta y$ ih $\mathrm{G}$ cells harboring the plasmids were grown in TB containing $0.2 \%(w / v)$ L-arabinose. The culture was transferred into a tube and vigorously shaken to shear off cell-associated flagella. The sample was centrifuged to spin down the cells, and the supernatant was passed through a filter with a pore size of $0.45 \mu \mathrm{m}$. The filtrated supernatant was concentrated with an Amicon Ultra device (30,000 MWCO), and the flagella in the supernatant were precipitated with trichloroacetic acid. The precipitates were subjected to SDS-PAGE and Western blot analysis using the rabbit anti-flagellin antibody [48]. The signal was detected using a peroxidase-conjugated anti-rabbit IgG antibody (Sigma, St. Louis, MO, USA) and Chemi-Lumi One Ultra (Nacalai Tesque, Kyoto, Japan).

\subsection{Transmission Electron Microscope (TEM) Observation of the Flagellar Structures}

TEM observation of the flagellar structures was performed according to the method described by Furuno et al. [49]. The BW25113 and $\Delta y i h G$ cells were grown at $37^{\circ} \mathrm{C}$ on $\mathrm{TB} 1.5 \%(w / v)$ agar plates until colonies were formed. Some colonies were scraped with a toothpick and gently suspended in $2.5 \mu \mathrm{L}$ of water to prevent detachment of the flagellar from the cells. Two microliters of the suspension was adsorbed onto a hydrophilized carbon-coated copper grid and then treated twice with $2 \%(w / v)$ phosphotungstic acid solution. The TEM images were obtained with a JEM-1400 transmission electron microscope (JEOL, Ltd., Tokyo, Japan) at an accelerating voltage of $120 \mathrm{kV}$. Images were acquired using a charge-coupled device camera (a built-in camera in the JEM-1400).

\section{Results}

\subsection{Identification of YihG in E. coli as an SlPlsC4 Ortholog}

Analysis of the E. coli genome using the BLAST program with the S1PlsC4 amino acid sequence (accession number, BBD74888) as a query revealed that E. coli YihG (accession number, AIN34165), a putative membrane acyltransferase, is an SIPlsC4 ortholog. The pairwise sequence alignment using the EMBOSS Needle global alignment tool (https://www.ebi.ac.uk/Tools/psa/emboss_needle/) showed that the amino acid sequence of YihG shares 39.1\% identity with that of SIPlsC4. YihG contains highly conserved acyltransferase motifs I-III but does not contain a motif IV like SIPlsC4 (Figure S1) [32,39]. These results suggested that YihG has a similar enzymatic activity to SIPlsC4.

\subsection{Overexpression of YihG in an E. coli plsC Mutant Allows its Growth at Non-Permissive Temperatures}

To examine whether YihG is a functional LPAAT homolog, we performed in vivo complementation assays using E. coli strain JC201, carrying a temperature-sensitive mutation in plsC. This strain grows normally at $30{ }^{\circ} \mathrm{C}$, but not at higher temperatures [35]. The pBAD derivatives, expressing YihG or PlsC upon induction by L-arabinose, were introduced into JC201 cells, and the transformants were tested for their ability to grow at non-permissive temperatures. In plate assays, cells expressing the recombinant YihG grew well at $42{ }^{\circ} \mathrm{C}$ in the presence of $2 \%$ L-arabinose but showed no or marginal growth in the presence of 0 to $1 \%$ L-arabinose (Figure $1 \mathrm{~A}$ and Figure S2). No complementation was observed in cells harboring the empty vector under the same conditions (Figure 1A and Figure S2). Thus, it was demonstrated that YihG, like PlsC, can act as an LPAAT in vivo. 
A

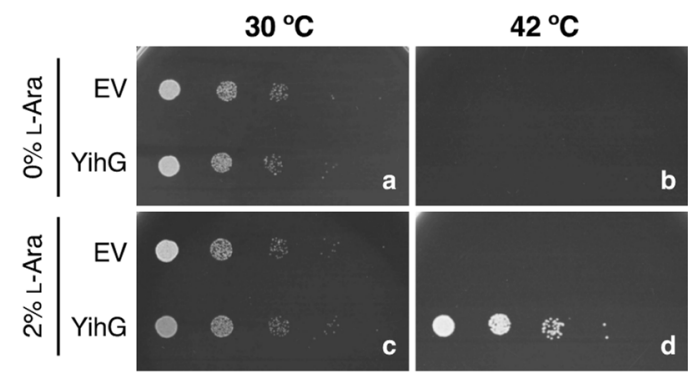

B

$-\mathrm{EV} \quad \triangle$ YihG $\quad-$ PIsC

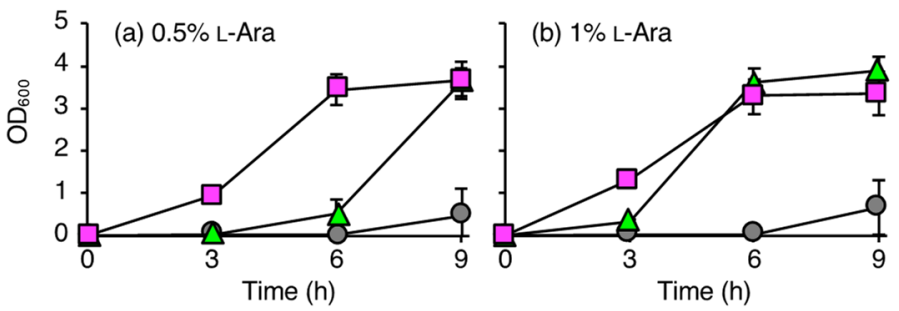

C

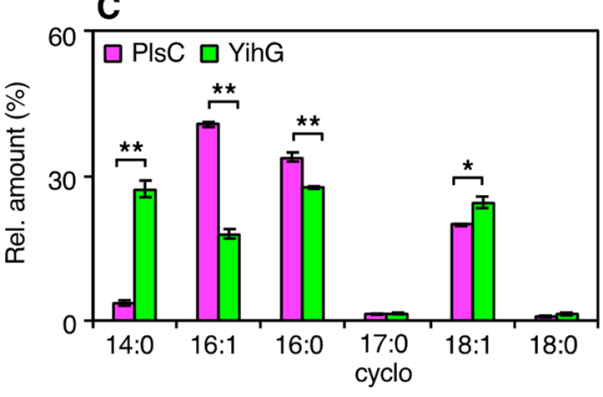

D $E$

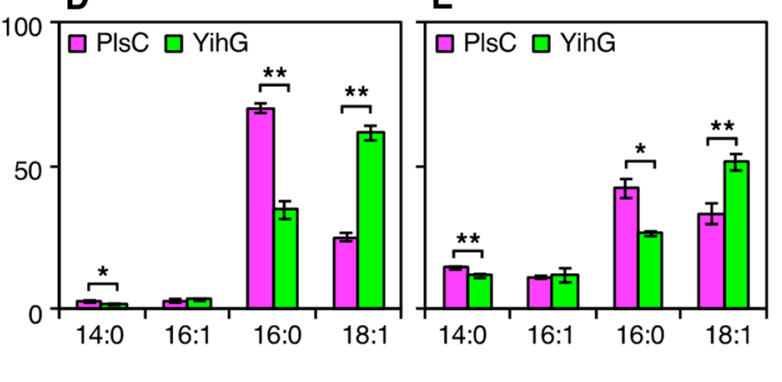

Figure 1. Overexpression of YihG and PlsC in JC201 cells. (A) Serially diluted JC201 cells harboring the pBAD-Cm ${ }^{\mathrm{R}}$ empty vector (EV) or pBAD/yihG-his ${ }_{6}$ (YihG) were grown on LB plates containing $0 \%$ or $2 \%$ L-arabinose at $30{ }^{\circ} \mathrm{C}(\mathrm{a}, \mathrm{c})$ and $42{ }^{\circ} \mathrm{C}(\mathrm{b}, \mathrm{d})$ for 12-14 h. (B) JC201 cells harboring the pBAD-Cm ${ }^{\mathrm{R}}$ empty vector (EV, gray), pBAD/yihG-his ${ }_{6}$ (YihG, light green), or $\mathrm{pBAD} / \mathrm{plsC}$-his s $_{6}$ (PlsC, magenta) were grown in LB containing $0.5 \%$ (a) or $1 \%$ (b) L-arabinose at $37^{\circ} \mathrm{C}$. Each data point is the average of three biological replicates \pm SD. (C-E) The fatty acyl composition of phospholipids (PLs) from JC201 cells overexpressing YihG and PlsC. Total PL extracts were hydrolyzed by PLA2, and the resulting fatty acids were analyzed by GC-MS (C), whereas the resulting lysophosphatidylethanolamines (LPEs) and lysophosphatidylglycerols (LPGs) were analyzed by ESI-MS (D and E, respectively). The graphs show the relative amounts of the fatty acids and lysophospholipids (LPLs) from JC201 cells harboring pBAD/plsC-his ${ }_{6}$ (PlsC, magenta) or pBAD/yihG-his 6 (YihG, light green). The cyclopropane derivative of $16: 1$ is indicated as 17:0cyclo $(C)$. Data are shown as the mean $\pm \operatorname{SD}(n=3)$. Statistical analysis was performed using Welch's $t$-test: ${ }^{*}, p<0.05 ;{ }^{* *}, p<0.01$.

To investigate the physiological contribution of YihG to cell growth, we compared the growth rates of JC201 cells overexpressing YihG with JC201 cells overexpressing PlsC (Figure 1B). JC201 cells harboring the empty vector hardly grew at $37^{\circ} \mathrm{C}$. However, cells overexpressing PlsC showed vigorous growth at $37^{\circ} \mathrm{C}$ in the presence of both $0.5 \%$ and $1 \%$-arabinose. The growth rate of cells overexpressing YihG at $37^{\circ} \mathrm{C}$ was much slower than that of cells overexpressing PlsC in the presence of $0.5 \%$ L-arabinose, but these strains grew similarly in the presence of $1 \%$ L-arabinose. These results indicated that YihG, expressed following L-arabinose induction, suppresses the growth defect of an E. coli plsC mutant at non-permissive temperatures in a quantity-dependent manner. 


\subsection{In vivo Substrate Specificity of YihG is Different from that of PlsC}

To compare the in vivo substrate specificities of YihG and PlsC, we analyzed the fatty acyl composition of PLs from JC201 cells overexpressing YihG or PlsC grown at $37^{\circ} \mathrm{C}$ in the presence of $1 \%$ L-arabinose. The sn-2 ester bonds of PLs were hydrolyzed by PLA2, and the resulting free fatty acids were analyzed by GC-MS, whereas the resulting lysophosphatidylethanolamines (LPEs) and lysophosphatidylglycerols (LPGs) were analyzed by ESI-MS. As shown in Figure 1C, the palmitoleoyl group (16:1) and the palmitoyl group (16:0) were more abundant in cells overexpressing PlsC, whereas the myristoyl group (14:0) and the cis-vaccenoyl group (18:1) were more abundant in cells overexpressing YihG, indicating that YihG preferably introduces 14:0 and 18:1 into the sn-2 position of PLs compared with PlsC. As shown in Figure 1D and E, 16:0-LPE and 16:0-LPG were the most abundant LPLs in cells overexpressing PlsC, whereas 18:1-LPE and 18:1-LPG were the most abundant LPLs in cells overexpressing YihG, indicating that YihG preferably introduces fatty acyl groups into the PLs containing 18:1 at the $s n-1$ position compared with PlsC. Thus, we concluded that YihG and PlsC have distinct in vivo substrate specificities.

\subsection{Deletion of Endogenous YihG Affects Membrane PL Composition}

To investigate the role of endogenous YihG in PL biosynthesis in E. coli cells, we analyzed the PL composition of $\Delta y i h G$ cells grown at $37^{\circ} \mathrm{C}$ in TB. The PL extracts were subjected to ESI-MS/MS analysis, and the compositions of PE and PG molecular species were determined by their ion peak intensities (Figure 2A,B). The fatty acyl chains in each PL species are summarized in Tables S3 and S4. In $\Delta y$ ih $G$ cells, the levels of 34:2-PE, 34:2-PG, 36:2-PE, and 36:2-PG containing 18:1 decreased compared with those in wild-type cells. The amounts of these PLs were increased when the YihG-expression plasmid was introduced into $\triangle y i h G$ cells. These results suggest that YihG is involved in the biosynthesis of PLs containing 18:1. The amounts of 34:1-PE and 34:1-PG containing 18:1 also decreased in $\Delta y i h G$ cells compared with those in wild-type cells. However, these PLs further decreased when the YihG-expression plasmid was introduced into $\Delta y i h G$ cells. A possible reason for this will be described in the Discussion.

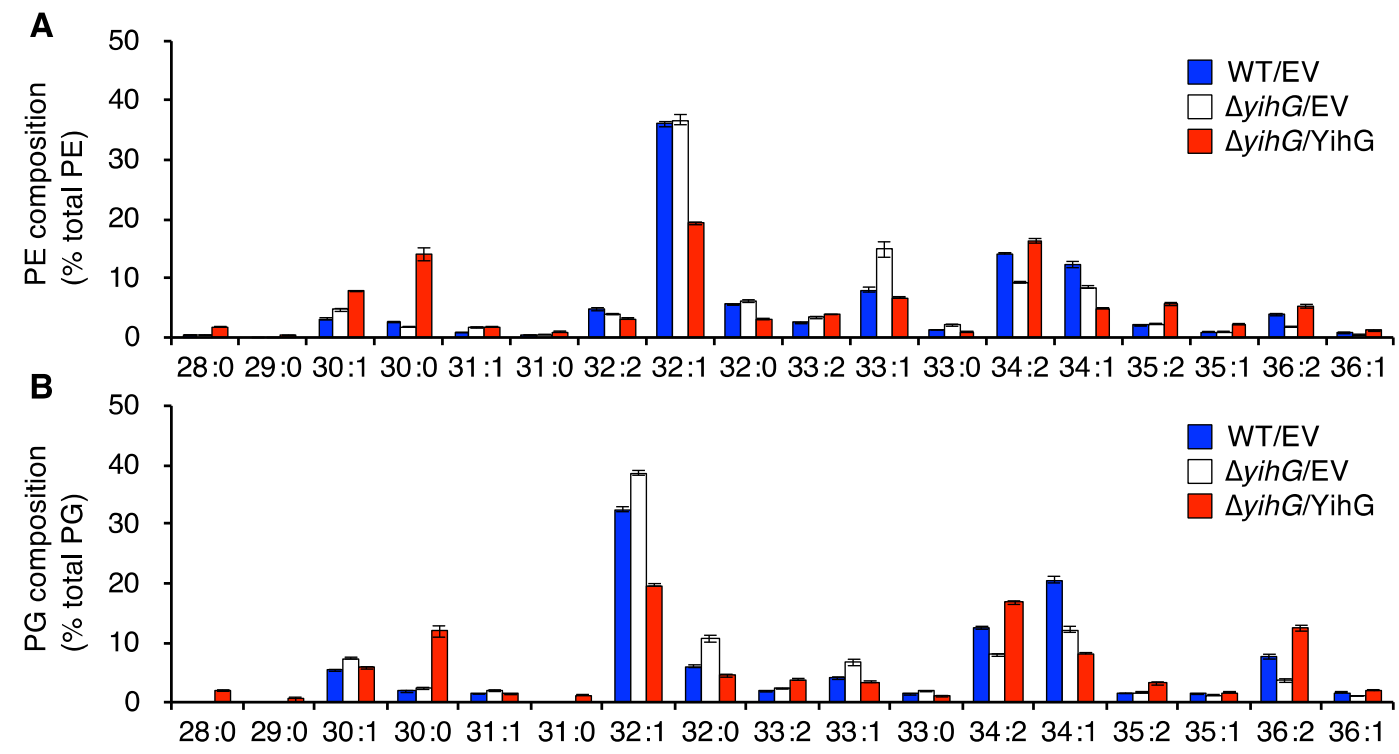

Figure 2. Effects of yih $G$ disruption on PL composition. Total PLs extracted from cells grown at $37^{\circ} \mathrm{C}$ to an $\mathrm{OD}_{600}$ of 0.6-0.8 were analyzed by ESI-MS/MS. The graphs show the composition of PE (A) and PG (B) derived from wild-type cells harboring the pBAD-Cm ${ }^{\mathrm{R}}$ empty vector (WT/EV, blue) and $\Delta y i h G$ cells harboring the pBAD-Cm ${ }^{\mathrm{R}}$ empty vector ( $\Delta$ yihG/EV, white) or pBAD/yihG-his ${ }_{6}(\Delta y i h G / Y i h G$, red). Data are shown as the mean $\pm \operatorname{SD}(n=3)$. 
To confirm that endogenous YihG introduces 18:1 into the sn-2 position of PLs, we analyzed the sn-2 fatty acyl group composition of PLs from $\Delta y i h G$ cells. The sn-2 ester bonds of PLs were hydrolyzed by PLA2. The resulting free fatty acids were subjected to GC-MS analysis, and the composition of the fatty acids was determined by their peak intensities (Figure 3). When compared with wild-type cells, the amount of 18:1 linked to the $s n-2$ position significantly decreased in $\Delta y i h G$ cells. This result indicated that YihG introduces 18:1 into the sn-2 position of PLs. Consistently, the amount of 18:1 significantly increased when the YihG-expression plasmid was introduced into $\Delta y i h G$ cells. The amount of 14:0 drastically increased when the YihG-expression plasmid was introduced into $\Delta y i h G$ cells. The reason for this could be explained by the substrate preference of YihG for 14:0 (Figure 1C).

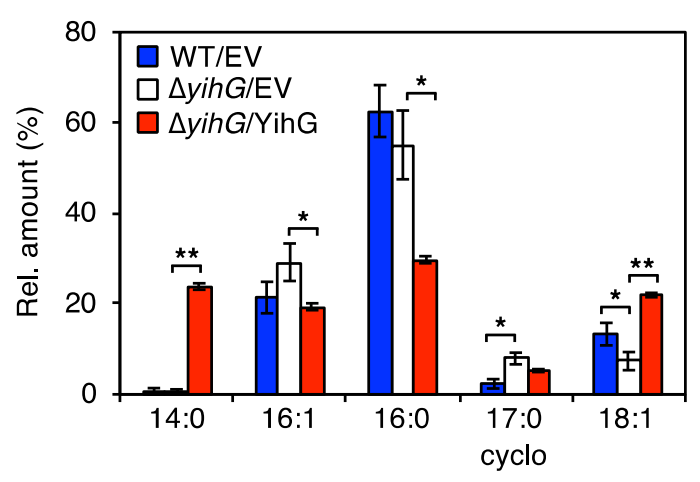

Figure 3. Effects of yih $G$ disruption on the fatty acyl group at the $s n-2$ position of PLs. Total PL extracts were hydrolyzed by PLA2, and the resulting fatty acids were analyzed by GC-MS. The graph shows the relative amounts of the fatty acids from wild-type cells harboring the pBAD-Cm ${ }^{\mathrm{R}}$ empty vector (WT/EV, blue) and $\Delta y i h G$ cells harboring the pBAD-Cm ${ }^{R}$ empty vector ( $\Delta y i h G / E V$, white) or pBAD/yihG-his ${ }_{6}$ $(\Delta y i h G / Y i h G$, red). Data are shown as the mean \pm SD $(n=3)$. The cyclopropane derivative of 16:1 is indicated as 17:0cyclo. Statistical analysis was performed using Welch's t-test: ${ }^{*}, p<0.05 ;{ }^{* *}, p<0.01$.

\subsection{The Deletion of Endogenous YihG Causes Enhanced Swimming Motility}

To investigate the physiological role of YihG in E. coli cells, we characterized the growth phenotype of $\Delta y$ ih $G$ cells. $\Delta y i h G$ cells were cultured in $L B$ and minimal medium at various temperatures. We found that the lack of YihG has no or only marginal effects on the growth of E. coli cells under these conditions (Figure S3).

We subsequently monitored bacterial motility by spotting the cell cultures on TB soft agar plates. E. coli BW25113 is known as a motility-impaired strain due to the low transcription level of motility-related genes compared with other motile E. coli strains [50]. However, interestingly, $\Delta y i h G$ cells showed a much larger swimming halo compared with wild-type cells after $12 \mathrm{~h}$ incubation at $37^{\circ} \mathrm{C}$ (Figure $4 \mathrm{~A}$ ), although the growth rate of $\Delta y i h \mathrm{G}$ cells was very similar to that of wild-type cells in $\mathrm{TB}$ at $37^{\circ} \mathrm{C}$ (Figure S4). Motility of $\Delta y$ ih $\mathrm{G}$ cells harboring the YihG-expression plasmid was also assayed. These cells were incubated on plates containing $0.02 \%$ or $0.2 \%$ L-arabinose for $15 \mathrm{~h}$ (Figure $4 \mathrm{~B}$ ). The induction of YihG with $0.02 \%$ L-arabinose did not affect the motility of $\Delta y i h G$ cells. However, cells overexpressing YihG in the presence of $0.2 \%$ L-arabinose did not show the enhanced motility compared with cells harboring the empty vector. These results suggested that YihG is related to the bacterial motility.

We further checked the motility phenotype of $\Delta y$ ih G cells in solution (Figure $4 \mathrm{C}, \mathrm{D}$, and Video S1). The cells were grown at $37^{\circ} \mathrm{C}$ in $\mathrm{TB}$ to an $\mathrm{OD}_{600}$ of 0.6 to 0.8 and observed under the microscope at room temperature. Wild-type cells did not show any directional swimming motion but diffused freely in solution. In contrast, more than half of $\Delta y i h G$ cells swam smoothly in solution, and only a small proportion of cells showed a jiggling motion. The fraction of the swimming cells was $59 \pm 4 \%$ (mean $\pm \mathrm{SD}$, four assays), and their speed was $15 \pm 5 \mu \mathrm{m} / \mathrm{s}$ (mean $\pm \mathrm{SD}, 59$ cells). These results indicated that the motility machinery, the flagellum, functions well in $\triangle y i h G$ cells compared to wild-type cells. 
A
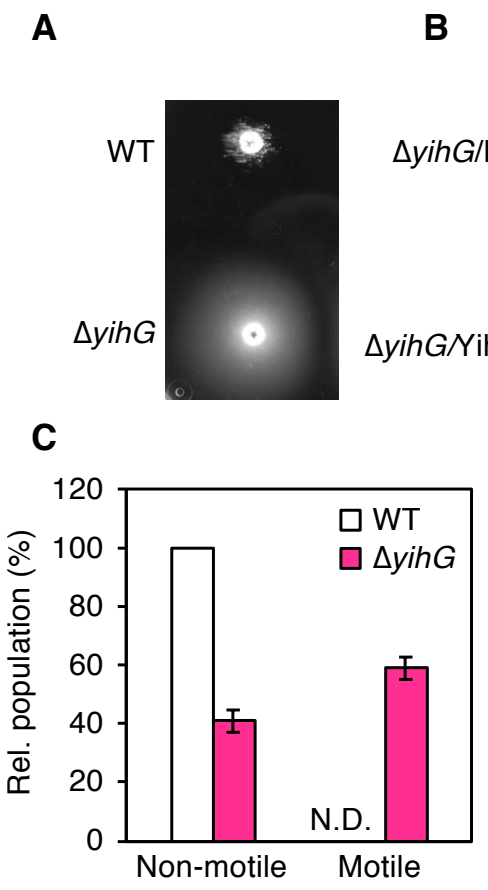

B

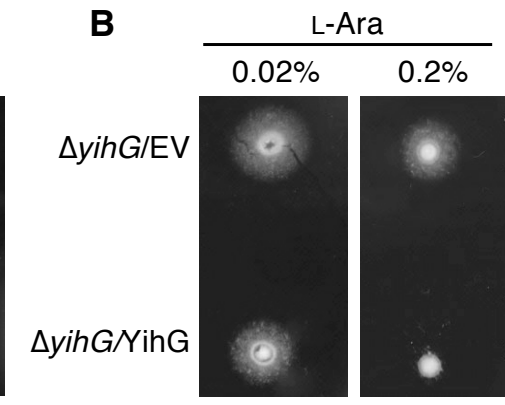

D

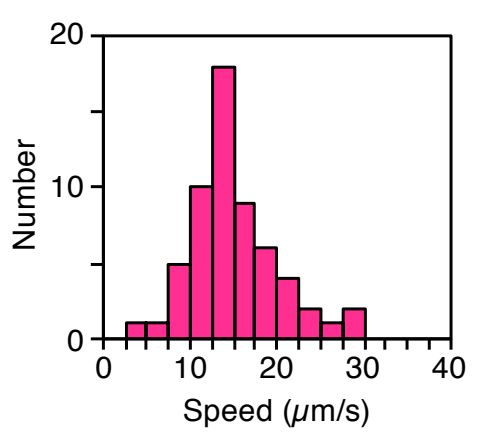

E

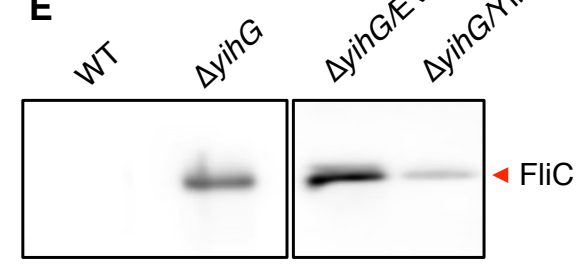

$\mathbf{F}$
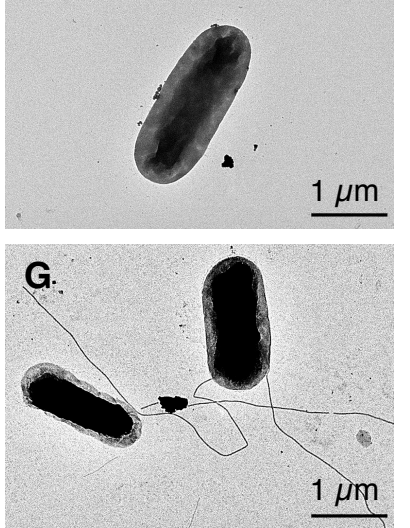

Figure 4. Characterization of the swimming motility of the E. coli cells. (A) Motilities of wild-type and $\Delta y i h G$ cells on the $0.2 \%$ agar plate. The plate was incubated at $37^{\circ} \mathrm{C}$ for $12 \mathrm{~h}$. (B) Motilities of $\Delta y i h G$ cells harboring the pBAD-Cm ${ }^{\mathrm{R}}$ empty vector $(\Delta y i h \mathrm{G} / \mathrm{EV})$ or $\mathrm{pBAD} / \mathrm{yih} G-h_{i s_{6}}(\Delta y i h G / \mathrm{YihG})$ on the $0.2 \%$ agar plates containing $0.02 \%$ or $0.2 \%$ L-arabinose. The plates were incubated at $37{ }^{\circ} \mathrm{C}$ for $15 \mathrm{~h}$.

(C) Motility of the E. coli cells in solution. Wild-type (white) and $\Delta y i h G$ (pink) cells were grown at $37^{\circ} \mathrm{C}$ to an $\mathrm{OD}_{600}$ of $0.6-0.8$ and observed under the microscope. Relative populations of motile and non-motile cells were calculated. Data are shown as the average of four biological replicates \pm SD. N.D., not detected. (D) Histogram of the swimming speed of motile $\Delta y i h G$ cells. (E) Effects of yihG disruption on the flagellar formation of E. coli cells. Flagellin was separated from wild-type and $\Delta y i h G$ cells grown at $37^{\circ} \mathrm{C}$ to an $\mathrm{OD}_{600}$ of $0.6-0.8$ and analyzed by Western blot analysis. Flagellin was also separated from $\Delta y i h G$ cells harboring the $\mathrm{pBAD}-\mathrm{Cm}^{\mathrm{R}}$ empty vector $(\Delta y i h G / \mathrm{EV})$ or $\mathrm{pBAD} / \mathrm{yih}_{\mathrm{h}}-h_{i s_{6}}$ ( $\triangle$ yihG/YihG) grown at $37^{\circ} \mathrm{C}$ to an $\mathrm{OD}_{600}$ of $0.6-0.8$ and analyzed by Western blot analysis. $(\mathrm{F}, \mathrm{G}) \mathrm{TEM}$ observation of the flagellar structures of the E. coli cells. Wild-type $(\mathbf{F})$ and $\Delta y i h G(\mathbf{G})$ cells were grown at $37^{\circ} \mathrm{C}$ on TB agar plates and observed under the TEM.

E. coli cells swim by rotating flagellar filaments [51-54], and the speed of swimming cells is dependent on the number of flagellar filaments [55]. Therefore, we analyzed the flagellar expression of wild-type and $\Delta y i h G$ cells. E. coli flagellin (FliC) was isolated from the cells and analyzed by Western blot analysis. As shown in Figure 4E, FliC was highly expressed in $\Delta y i h G$ cells compared to wild-type cells. In addition, this phenotype was suppressed by introduction of the YihG-expression plasmid into the mutant and expression of YihG by addition of $0.2 \%$ L-arabinose. Finally, the flagellar formation was confirmed by electron microscopy. Wild-type cells showed no evidence of flagellar filaments (Figure $4 F$ ). In contrast, approximately half of $\Delta y i h G$ cells had one or two flagellar filaments (Figure $4 G$ ). Taking these data together, we concluded that loss of YihG promotes the formation of the functional flagella, leading to the enhanced swimming motility.

\section{Discussion}

To assess the in vivo function of an SlPlsC4 ortholog of E. coli named YihG, we conducted a complementation assay using E. coli JC201 cells. Overproduction of YihG suppressed the temperature-sensitive phenotype of E. coli JC201 carrying a mutated plsC (Figure 1A,B and Figure S2), 
demonstrating that YihG has LPAAT activity. GC-MS analysis of $s n-2$ fatty acyl groups and ESI-MS analysis of 1-acyl LPLs (Figure 1C-E) revealed that YihG facilitates the synthesis of PLs containing 14:0 and 18:1 at the $s n-2$ position and 18:1 at the $s n-1$ position, whereas PlsC facilitates the synthesis of PLs containing 16:1 and 16:0 at the $s n-2$ position and 16:0 at the $s n-1$ position. Thus, the in vivo substrate specificities of YihG and PlsC are clearly different from each other. To our knowledge, this is the first report showing that $E$. coli expresses two functional LPAAT homologs with different substrate specificities. It is notable that deletion of $\mathrm{pls} C$ is lethal, and that endogenous YihG cannot suppress the growth defect of JC201 cells at non-permissive temperatures. This may be due to low expression of the endogenous YihG. In fact, an increase in the L-arabinose concentration led to a corresponding increase in the growth rate of JC201 cells harboring arabinose-controlled YihG-expression plasmid (Figure 1B).

Next, to unveil the physiological role of endogenous YihG in E. coli, we analyzed the effects of yihG disruption on PL biosynthesis in E. coli BW25113. ESI-MS/MS analysis of PLs (Figure 2) and GC-MS analysis of the $s n-2$ fatty acyl groups (Figure 3) revealed that endogenous YihG plays a major role in the synthesis of PLs containing 18:1 at the sn-2 position. However, 18:1 at the sn-2 position of PLs still remained in $\triangle y i h G$ cells (levels were approximately a half of that in wild-type cells). Thus, endogenous $\mathrm{PlsC}$ also contributes to the synthesis of PLs containing 18:1 at the $s n-2$ position. In fact, PL species containing 18:1 (34:2-PE, 34:2-PG, 34:1-PE, 34:1-PG, 36:2-PE, and 36:2-PG) were still synthesized in $\triangle y i h G$ cells, even though some of these PLs possibly contain 18:1 at their sn-1 positions. The amount of some PL species containing 18:1 (34:1-PE and 34:1-PG) further decreased when the YihG-expression plasmid was introduced into $\triangle y i h G$ cells (Figure 2). These results may be due to overexpression of yihG under the control of the $\mathrm{P}_{\mathrm{BAD}}$ promoter [41]. Overproduced YihG is supposed to facilitate incorporation of 14:0 on the acyl carrier protein of fatty acid synthase into 16:0-LPA to produce 30:0-PE and 30:0-PG (Figures 2 and 3) and cause deficiency of 16:0-LPA for the synthesis of other PL species, such as 34:1-PE and 34:1-PG. Consistent with this speculation, the abundance of 32:1-PE and 32:1-PG containing 16:0 also drastically decreased when YihG was overexpressed in $\triangle y i h G$ cells (Figure 2).

Various bacteria, including N. meningitidis, P. fluorescens, P. aeruginosa, R. capsulatus, and S. livingstonensis Ac10, produce multiple LPAAT homologs [24-27,32]. However, there is no report describing the occurrence of an LPAAT homolog that preferentially produces PLs containing 18:1 in bacterial cells under physiological conditions. Thus, YihG is a new type of LPAAT homolog that plays a major role in the synthesis of PLs containing 18:1 at the $s n-2$ position under physiological conditions. Although YihG was identified as an ortholog of SIPlsC4 derived from S. livingstonensis Ac10, the in vivo substrate specificities of YihG and SIPlsC4 are different from each other. YihG prefers 14:0 and 18:1 as acyl donor substrates (Figure 1C), whereas SIPlsC4 prefers i13:0, 14:0, and i15:0 as acyl donor substrates [34]. This is possibly explained by the differences in the size and shape of their hydrophobic tunnels which accommodate the acyl chains of the acyl-acyl carrier protein or coenzyme A [22]. To understand the molecular basis of substrate specificity of YihG and SIPlsC4, biochemical and structural analyses should be conducted in the future.

In bacteria, PLs that contain low-melting-point fatty acids, such as monounsaturated fatty acids, contribute to the maintenance of membrane fluidity for their optimal growth at low temperatures. In fact, a decrease in monounsaturated fatty acids in the membrane leads to growth defects in some bacteria at low temperatures [7]. However, in the case of $E$. coli, the growth rate of $\Delta y i h G$ cells at $18^{\circ} \mathrm{C}$ was barely distinguishable from that of wild-type cells (Figure S3). Thus, PLs containing 18:1 produced by YihG are not essential for the growth of $E$. coli at low temperatures. $\triangle y i h G$ cells still contain a large amount of $16: 1$ and $18: 1$, constituting $36.5 \%$ of the total fatty acids at the sn-2 position of PLs (Figure 3), and this may contribute to the maintenance of the membrane fluidity for the growth of this bacterium.

Interestingly, the deletion of YihG enhanced swimming motility and caused abnormal flagellar production (Figure 4). The expression of motility-related genes is tightly regulated in E. coli, and these genes are arranged in hierarchical order into three classes (I, II, and III) [51]. At the top of the hierarchy is the class I operon containing the $f l h D C$ genes called the master operon. Motile E. coli strains like MG1655 and W3110 contain insertion sequence elements IS1 or IS5 in the regulatory region 
of the $f l h D C$ promoter, and this leads to dramatic activation of the master operon that is otherwise silenced [56,57]. In contrast, poorly motile E. coli strains like BW25113 lack such an insertion element in the corresponding region $[57,58]$. According to this fact, the following reasons may account for the abnormal flagellar production by E. coli BW25113 in the absence of yih G. First, flhDC expression may be derepressed in $\triangle y i h G$ cells due to envelope stress induced by changing membrane PL composition [59], given that a certain bacterial signal transduction system responds to the perturbations in membrane lipid properties [60-63]. Second, YihG may affect the cellular ratio of DnaA-ATP/DnaA-ADP [40], which not only regulates DNA replication [64,65], but also affects flhDC expression [66,67]. An ATP/ADP switch of DnaA defines its DNA-binding activity [68], and this conversion is in part promoted by highly unsaturated membrane PLs [69,70]. Thus, membrane PLs generated by YihG may regulate the cellular DnaA-ATP level, coordinating the DNA replication and the flhDC expression. YihG is also conserved in some $\gamma$-proteobacteria such as S. typhimurium and V. cholerae, and flagella play an important role in the adhesion and invasion of these pathogenic cells [71]. We propose that YihG may affect the virulence of these bacteria by regulating flagellar formation according to environmental changes. The details of the mechanism by which YihG affects the flagellar formation should be clarified in the future.

\section{Conclusions}

In this study, we characterized the in vivo function of YihG, a novel E. coli LPAAT homolog, and further investigated its physiological roles. Analysis of the fatty acyl composition of PLs from JC201 cells overexpressing YihG and PlsC revealed that YihG facilitates the synthesis of PLs containing 14:0 and 18:1 at the $s n-2$ position and 18:1 at the $s n-1$ position, whereas PlsC facilitates the synthesis of PLs containing 16:1 and 16:0 at the $s n-2$ position and 16:0 at the $s n-1$ position, thus demonstrating that $E$. coli has two functional LPAAT homologs with different substrate specificities. Analysis of the fatty acyl composition of PLs from $\triangle y i h G$ cells revealed that endogenous YihG introduces 18:1 into the $s n-2$ position of PLs. Phenotypic analysis revealed that the lack of YihG causes high expression of FliC and enhances swimming motility but does not affect cell growth or morphology. In addition, the flagellar structure was observed only in $\triangle y i h G$ cells. These results suggested that $\mathrm{PlsC}$ is responsible for the synthesis of the majority of membrane PLs, whereas YihG has more specific functions related to flagellar formation via modulation of the fatty acyl composition of membrane PLs.

Supplementary Materials: The following are available online at http://www.mdpi.com/2218-273X/10/5/745/s1, Figure S1: Multiple sequence alignment of YihG, S1PlsC4, and PlsC; Figure S2: Overexpression of YihG in JC201 cells; Figure S3: Growth characteristics of $\Delta y i h G$ cells in LB and minimal medium; Figure S4: Growth characteristics of $\Delta y i h G$ cells in TB; Table S1: Bacterial strains and plasmids used in this study; Table S2: Sequences of primers used in this study; Table S3: Fatty acyl groups of PEs from wild-type and $\triangle y i h G$ cells harboring the plasmids found in Figure 2A; Table S4: Fatty acyl groups of PGs from wild-type and $\Delta y i h G$ cells harboring the plasmids found in Figure 2B. Video S1: Observation of swimming $\Delta y i h G$ cells in liquid medium.

Author Contributions: Conceptualization, Y.T. and T.K.; biochemical and molecular biological analysis, Y.T.; swimming analysis, Y.T. and M.N.; TEM observation, F.Y.; writing—original draft preparation, Y.T. and T.K.; writing-review and editing, Y.T., M.N., F.Y., T.O., J.K., and T.K.; supervision, M.N. and T.K.; project administration, T.K.; funding acquisition, M.N., T.O., and T.K. All authors have read and agreed to the published version of the manuscript.

Funding: This work was supported by JSPS KAKENHI (Grant Number JP16K04908 and JP17KT0026 to M.N., JP17K15259 to T.O. and JP18H02127 to T.K.).

Acknowledgments: TEM observation was performed in collaboration with the Analysis and Development System for Advanced Materials (ADAM) in the Research Institute for Sustainable Humanosphere, Kyoto University. We thank Michio Homma, Associate Seiji Kojima, and Kimika Maki (Nagoya University) for their discussions and technical support.

Conflicts of Interest: The authors have no conflict of interest to declare. 


\section{References}

1. Cornell, B.A.; Separovic, F. Membrane thickness and acyl chain length. Biochim. Biophys. Acta Biomembr. 1983, 733, 189-193. [CrossRef]

2. Lewis, B.A.; Engelman, D.M. Lipid bilayer thickness varies linearly with acyl chain length in fluid phosphatidylcholine vesicles. J. Mol. Biol. 1983, 166, 211-217. [CrossRef]

3. Mykytczuk, N.C.S.; Trevors, J.T.; Leduc, L.G.; Ferroni, G.D. Fluorescence polarization in studies of bacterial cytoplasmic membrane fluidity under environmental stress. Prog. Biophys. Mol. Biol. 2007, 95, 60-82. [CrossRef]

4. Mostofian, B.; Zhuang, T.; Cheng, X.; Nickels, J.D. Branched-chain fatty acid content modulates structure, fluidity, and phase in model microbial cell membranes. J. Phys. Chem. B 2019, 123, 5814-5821. [CrossRef] [PubMed]

5. Nagamachi, E.; Shibuya, S.; Hirai, Y.; Matsushita, O.; Tomochika, K.; Kanemasa, Y. Adaptational changes of fatty acid composition and the physical state of membrane lipids following the change of growth temperature in Yersinia enterocolitica. Microbiol. Immunol. 1991, 35, 1085-1093. [CrossRef] [PubMed]

6. Annous, B.A.; Becker, L.A.; Bayles, D.O.; Labeda, D.P.; Wilkinson, B.J. Critical role of anteiso-C15:0 fatty acid in the growth of Listeria monocytogenes at low temperatures. Appl. Environ. Microbiol. 1997, 63, 3887-3894. [CrossRef]

7. Allen, E.E.; Facciotti, D.; Bartlett, D.H. Monounsaturated but not polyunsaturated fatty acids are required for growth of the deep-sea bacterium Photobacterium profundum SS9 at high pressure and low temperature. Appl. Environ. Microbiol. 1999, 65, 1710-1720. [CrossRef] [PubMed]

8. Knoblauch, C.; Sahm, K.; Jorgensen, B.B. Psychrophilic sulfate-reducing bacteria isolated from permanently cold Arctic marine sediments: Description of Desulfofrigus oceanense gen. nov., sp. nov., Desulfofrigus fragile sp. nov., Desulfofaba gelida gen. nov., sp. nov., Desulfotalea psychrophila gen. nov., sp. nov. and Desulfotalea arctica sp. nov. Int. J. Syst. Bacteriol. 1999, 49, 1631-1643.

9. Kawamoto, J.; Kurihara, T.; Yamamoto, K.; Nagayasu, M.; Tani, Y.; Mihara, H.; Hosokawa, M.; Baba, T.; Sato, S.B.; Esaki, N. Eicosapentaenoic acid plays a beneficial role in membrane organization and cell division of a cold-adapted bacterium, Shewanella livingstonensis Ac10. J. Bacteriol. 2009, 191, 632-640. [CrossRef]

10. Wang, F.; Xiao, X.; Ou, H.Y.; Gai, Y.; Wang, F. Role and regulation of fatty acid biosynthesis in the response of Shewanella piezotolerans WP3 to different temperatures and pressures. J. Bacteriol. 2009, 191, 2574-2584. [CrossRef]

11. Poerschmann, J.; Spijkerman, E.; Langer, U. Fatty acid patterns in Chlamydomonas sp. as a marker for nutritional regimes and temperature under extremely acidic conditions. Microb. Ecol. 2004, 48, 78-89. [CrossRef] [PubMed]

12. Yumoto, I.; Hirota, K.; Iwata, H.; Akutsu, M.; Kusumoto, K.; Morita, N.; Ezura, Y.; Okuyama, H.; Matsuyama, H. Temperature and nutrient availability control growth rate and fatty acid composition of facultatively psychrophilic Cobetia marina strain L-2. Arch. Microbiol. 2004, 181, 345-351. [CrossRef] [PubMed]

13. Drouin, P.; Prévost, D.; Antoun, H. Physiological adaptation to low temperatures of strains of Rhizobium leguminosarum bv. viciae associated with Lathyrus spp. FEMS Microbiol. Ecol. 2000, 32, 111-120. [PubMed]

14. Kennedy, E.P.; Weiss, S.B. The function of cytidine coenzymes in the biosynthesis of phospholipides. J. Biol. Chem. 1956, 222, 193-214. [PubMed]

15. Zhang, Y.M.; Rock, C.O. Thematic review series: Glycerolipids. Acyltransferases in bacterial glycerophospholipid synthesis. J. Lipid Res. 2008, 49, 1867-1874. [CrossRef] [PubMed]

16. Yao, J.; Rock, C.O. Phosphatidic acid synthesis in bacteria. Biochim. Biophys. Acta Mol. Cell Biol. Lipids 2013, 1831, 495-502. [CrossRef]

17. Parsons, J.B.; Rock, C.O. Bacterial lipids: Metabolism and membrane homeostasis. Prog. Lipid Res. 2013, 52, 249-276. [CrossRef]

18. Lightner, V.A.; Larson, T.J.; Tailleur, P.; Kantor, G.D.; Raetz, C.R.H.; Bell, R.M.; Modrich, P. Membrane phospholipid synthesis in Escherichia coli. Cloning of a structural gene ( $p l s B)$ of the sn-glycerol-3-phosphate acyltransferase. J. Biol. Chem. 1980, 255, 9413-9420.

19. Green,P.R.; Merrill, A.H.; Bell, R.M. Membrane phospholipid synthesis in Escherichia coli. Purification, reconstitution, and characterization of sn-glycerol-3-phosphate acyltransferase. J. Biol. Chem. 1981, 256, 11151-11159. 
20. Lu, Y.J.; Zhang, Y.M.; Grimes, K.D.; Qi, J.; Lee, R.E.; Rock, C.O. Acyl-phosphates initiate membrane phospholipid synthesis in Gram-positive pathogens. Mol. Cell 2006, 23, 765-772. [CrossRef]

21. Coleman, J. Characterization of the Escherichia coli gene for 1-acyl-sn-glycerol-3-phosphate acyltransferase (plsC). MGG Mol. Gen. Genet. 1992, 232, 295-303. [CrossRef]

22. Robertson, R.M.; Yao, J.; Gajewski, S.; Kumar, G.; Martin, E.W.; Rock, C.O.; White, S.W. A two-helix motif positions the lysophosphatidic acid acyltransferase active site for catalysis within the membrane bilayer. Nat. Struct. Mol. Biol. 2017, 24, 666-671. [CrossRef]

23. Li, Z.; Tang, Y.; Wu, Y.; Zhao, S.; Bao, J.; Luo, Y.; Li, D. Structural insights into the committed step of bacterial phospholipid biosynthesis. Nat. Commun. 2017, 8, 1691. [CrossRef]

24. Shih, G.C.; Kahler, C.M.; Swartley, J.S.; Rahman, M.M.; Coleman, J.; Carlson, R.W.; Stephens, D.S. Multiple lysophosphatidic acid acyltransferases in Neisseria meningitidis. Mol. Microbiol. 1999, 32, 942-952. [CrossRef]

25. Cullinane, M.; Baysse, C.; Morrissey, J.P.; O'Gara, F. Identification of two lysophosphatidic acid acyltransferase genes with overlapping function in Pseudomonas fluorescens. Microbiology 2005, 151, 3071-3080. [CrossRef]

26. Baysse, C.; Cullinane, M.; Dénervaud, V.; Burrowes, E.; Dow, J.M.; Morrissey, J.P.; Tam, L.; Trevors, J.T.; O'Gara, F. Modulation of quorum sensing in Pseudomonas aeruginosa through alteration of membrane properties. Microbiology 2005, 151, 2529-2542. [CrossRef]

27. Aygun-Sunar, S.; Bilaloglu, R.; Goldfine, H.; Daldal, F. Rhodobacter capsulatus OlsA is a bifunctional enzyme active in both ornithine lipid and phosphatidic acid biosynthesis. J. Bacteriol. 2007, 189, 8564-8574. [CrossRef]

28. Sato, S.; Kawamoto, J.; Sato, S.B.; Watanabe, B.; Hiratake, J.; Esaki, N.; Kurihara, T. Occurrence of a bacterial membrane microdomain at the cell division site enriched in phospholipids with polyunsaturated hydrocarbon chains. J. Biol. Chem. 2012, 287, 24113-24121. [CrossRef]

29. Yokoyama, F.; Kawamoto, J.; Imai, T.; Kurihara, T. Characterization of extracellular membrane vesicles of an Antarctic bacterium, Shewanella livingstonensis Ac10, and their enhanced production by alteration of phospholipid composition. Extremophiles 2017, 21, 723-731. [CrossRef]

30. Tokunaga, T.; Watanabe, B.; Sato, S.; Kawamoto, J.; Kurihara, T. Synthesis and functional assessment of a novel fatty acid probe, $w$-ethynyl eicosapentaenoic acid analog, to analyze the in vivo behavior of eicosapentaenoic acid. Bioconjug. Chem. 2017, 28, 2077-2085. [CrossRef]

31. Kawai, S.; Kawamoto, J.; Ogawa, T.; Kurihara, T. Development of a regulatable low-temperature protein expression system using the psychrotrophic bacterium, Shewanella livingstonensis Ac10, as the host. Biosci. Biotechnol. Biochem. 2019, 83, 2153-2162. [CrossRef]

32. Cho, H.N.; Kasai, W.; Kawamoto, J.; Esaki, N.; Kurihara, T. Characterization of 1-acyl-sn-glycerol-3-phosphate acyltransferase from a polyunsaturated fatty acid-producing bacterium, Shewanella livingstonensis Ac10. Trace Nutr. Res. 2012, 29, 92-99.

33. Ogawa, T.; Tanaka, A.; Kawamoto, J.; Kurihara, T. Purification and characterization of 1-acyl-sn-glycerol-3-phosphate acyltransferase with a substrate preference for polyunsaturated fatty acyl donors from the eicosapentaenoic acid-producing bacterium Shewanella livingstonensis Ac10. J. Biochem. 2018, 164, 33-39. [CrossRef]

34. Toyotake, Y.; Cho, H.N.; Kawamoto, J.; Kurihara, T. A novel 1-acyl-sn-glycerol-3-phosphate O-acyltransferase homolog for the synthesis of membrane phospholipids with a branched-chain fatty acyl group in Shewanella livingstonensis Ac10. Biochem. Biophys. Res. Commun. 2018, 500, 704-709. [CrossRef]

35. Coleman, J. Characterization of Escherichia coli cells deficient in 1-acyl-sn-glycerol-3-phosphate acyltransferase activity. J. Biol. Chem. 1990, 265, 17215-17221.

36. Cao, G.J.; Pogliano, J.; Sarkar, N. Identification of the coding region for a second poly(A) polymerase in Escherichia coli. Proc. Natl. Acad. Sci. USA 1996, 93, 11580-11585. [CrossRef]

37. Mohanty, B.K.; Kushner, S.R. Residual polyadenylation in poly(A) polymerase I ( $p c n B$ ) mutants of Escherichia coli does not result from the activity encoded by the $f 310$ gene. Mol. Microbiol. 1999, 34, 1109-1119. [CrossRef]

38. Heath, R.J.; Rock, C.O. A conserved histidine is essential for glycerolipid acyltransferase catalysis. J. Bacteriol. 1998, 180, 1425-1430. [CrossRef]

39. Yamashita, A.; Nakanishi, H.; Suzuki, H.; Kamata, R.; Tanaka, K.; Waku, K.; Sugiura, T. Topology of acyltransferase motifs and substrate specificity and accessibility in 1-acyl-sn-glycero-3-phosphate acyltransferase 1. Biochim. Biophys. Acta Mol. Cell Biol. Lipids 2007, 1771, 1202-1215. [CrossRef] 
40. Babu, V.M.P.; Itsko, M.; Baxter, J.C.; Schaaper, R.M.; Sutton, M.D. Insufficient levels of the $n r d A B$-encoded ribonucleotide reductase underlie the severe growth defect of the $\Delta$ hda E. coli strain. Mol. Microbiol. 2017, 104, 377-399. [CrossRef]

41. Guzman, L.M.; Belin, D.; Carson, M.J.; Beckwith, J. Tight regulation, modulation, and high-level expression by vectors containing the arabinose $P_{\mathrm{BAD}}$ promoter. J. Bacteriol. 1995, 177, 4121-4130. [CrossRef]

42. Bligh, E.G.; Dyer, W.J. A rapid method of total lipid extraction and purification. Can. J. Biochem. Physiol. 1959, 37, 911-917. [CrossRef]

43. Dole, V.P. A relation between non-esterified fatty acids in plasma and the metabolism of glucose. J. Clin. Investig. 1956, 35, 150-154. [CrossRef]

44. Dole, V.P.; Meinertz, H. Microdetermination of long-chain fatty acids in plasma and tissues. J. Biol. Chem. 1960, 235, 2595-2599.

45. Ito, T.; Gong, C.; Kawamoto, J.; Kurihara, T. Development of a versatile method for targeted gene deletion and insertion by using the $p y r F$ gene in the psychrotrophic bacterium, Shewanella livingstonensis Ac10. J. Biosci. Bioeng. 2016, 122, 645-651. [CrossRef]

46. Nishiyama, M. High-pressure microscopy for tracking dynamic properties of molecular machines. Biophys. Chem. 2017, 231, 71-78. [CrossRef]

47. Nishiyama, M.; Arai, Y. Tracking the movement of a single prokaryotic cell in extreme environmental conditions. In The Bacterial Flagellum. Methods in Molecular Biology; Minamino, T., Namba, K., Eds.; Humana Press: New York, NY, USA, 2017; Volume 1593, pp. 175-184.

48. Nishiyama, M.; Kojima, S. Bacterial motility measured by a miniature chamber for high-pressure microscopy. Int. J. Mol. Sci. 2012, 13, 9225-9239. [CrossRef]

49. Furuno, M.; Atsumi, T.; Yamada, T.; Kojima, S.; Nishioka, N.; Kawagishi, I.; Homma, M. Characterization of polar-flagellar-length mutants in Vibrio alginolyticus. Microbiology 1997, 143, 1615-1621. [CrossRef]

50. Wood, T.K.; González Barrios, A.F.; Herzberg, M.; Lee, J. Motility influences biofilm architecture in Escherichia coli. Appl. Microbiol. Biotechnol. 2006, 72, 361-367. [CrossRef]

51. Berg, H.C. The rotary motor of bacterial flagella. Annu. Rev. Biochem. 2003, 72, 19-54. [CrossRef]

52. Kojima, S. Dynamism and regulation of the stator, the energy conversion complex of the bacterial flagellar motor. Curr. Opin. Microbiol. 2015, 28, 66-71. [CrossRef]

53. Nakamura, S.; Minamino, T. Flagella-driven motility of bacteria. Biomolecules 2019, 9, 279. [CrossRef]

54. Miyata, M.; Robinson, R.C.; Uyeda, T.Q.P.; Fukumori, Y.; Fukushima, S.; Haruta, S.; Homma, M.; Inaba, K.; Ito, M.; Kaito, C.; et al. Tree of motility-A proposed history of motility systems in the tree of life. Genes Cells 2020, 25, 6-21. [CrossRef]

55. Sakai, T.; Inoue, Y.; Terahara, N.; Namba, K.; Minamino, T. A triangular loop of domain D1 of FlgE is essential for hook assembly but not for the mechanical function. Biochem. Biophys. Res. Commun. 2018, 495, 1789-1794. [CrossRef]

56. Barker, C.S.; Prüß, B.M.; Matsumura, P. Increased motility of Escherichia coli by insertion sequence element integration into the regulatory region of the flhD operon. J. Bacteriol. 2004, 186, 7529-7537. [CrossRef]

57. Tamar, E.; Koler, M.; Vaknin, A. The role of motility and chemotaxis in the bacterial colonization of protected surfaces. Sci. Rep. 2016, 6, 19616. [CrossRef]

58. Wang, X.; Wood, T.K. IS5 inserts upstream of the master motility operon flhDC in a quasi-Lamarckian way. ISME J. 2011, 5, 1517-1525. [CrossRef]

59. Inoue, K.; Matsuzaki, H.; Matsumoto, K.; Shibuya, I. Unbalanced membrane phospholipid compositions affect transcriptional expression of certain regulatory genes in Escherichia coli. J. Bacteriol. 1997, 179, 2872-2878. [CrossRef]

60. Lai, H.C.; Soo, P.C.; Wei, J.R.; Yi, W.C.; Liaw, S.J.; Horng, Y.T.; Lin, S.M.; Ho, S.W.; Swift, S.; Williams, P. The RssAB two-component signal transduction system in Serratia marcescens regulates swarming motility and cell envelope architecture in response to exogenous saturated fatty acids. J. Bacteriol. 2005, 187, 3407-3414. [CrossRef]

61. Amin, D.N.; Hazelbauer, G.L. Influence of membrane lipid composition on a transmembrane bacterial chemoreceptor. J. Biol. Chem. 2012, 287, 41697-41705. [CrossRef]

62. Keller, R.; Ariöz, C.; Hansmeier, N.; Stenberg-Bruzell, F.; Burstedt, M.; Vikström, D.; Kelly, A.; Wieslander, Å.; Daley, D.O.; Hunke, S. The Escherichia coli Envelope Stress Sensor CpxA responds to changes in lipid bilayer properties. Biochemistry 2015, 54, 3670-3676. [CrossRef] 
63. Blanka, A.; Düvel, J.; Dötsch, A.; Klinkert, B.; Abraham, W.R.; Kaever, V.; Ritter, C.; Narberhaus, F.; Häussler, S. Constitutive production of c-di-GMP is associated with mutations in a variant of Pseudomonas aeruginosa with altered membrane composition. Sci. Signal. 2015, 8, ra36. [CrossRef]

64. Fuller, R.S.; Kornberg, A. Purified dnaA protein in initiation of replication at the Escherichia coli chromosomal origin of replication. Proc. Natl. Acad. Sci. USA 1983, 80, 5817-5821. [CrossRef]

65. Fuller, R.S.; Funnell, B.E.; Kornberg, A. The dnaA protein complex with the E. coli chromosomal replication origin (oriC) and other DNA sites. Cell 1984, 38, 889-900. [CrossRef]

66. Mizushima, T.; Tomura, A.; Shinpuku, T.; Miki, T.; Sekimizu, K. Loss of flagellation in dnaA mutants of Escherichia coli. J. Bacteriol. 1994, 176, 5544-5546. [CrossRef]

67. Mizushima, T.; Koyanagi, R.; Katayama, T.; Miki, T.; Sekimizu, K. Decrease in expression of the master operon of flagellin synthesis in a dnaA46 mutant of Escherichia coli. Biol. Pharm. Bull. 1997, 20, 327-331. [CrossRef]

68. Speck, C.; Weigel, C.; Messer, W. ATP- and ADP-DnaA protein, a molecular switch in gene regulation. EMBO J. 1999, 18, 6169-6176. [CrossRef]

69. Yung, B.Y.M.; Kornberg, A. Membrane attachment activates dnaA protein, the initiation protein of chromosome replication in Escherichia coli. Proc. Natl. Acad. Sci. USA 1988, 85, 7202-7205. [CrossRef]

70. Castuma, C.E.; Crooke, E.; Kornberg, A. Fluid membranes with acidic domains activate DnaA, the initiator protein of replication in Escherichia coli. J. Biol. Chem. 1993, 268, 24665-24668.

71. Haiko, J.; Westerlund-Wikström, B. The role of the bacterial flagellum in adhesion and virulence. Biology 2013, 2, 1242-1267. [CrossRef]

(C) 2020 by the authors. Licensee MDPI, Basel, Switzerland. This article is an open access article distributed under the terms and conditions of the Creative Commons Attribution (CC BY) license (http://creativecommons.org/licenses/by/4.0/). 